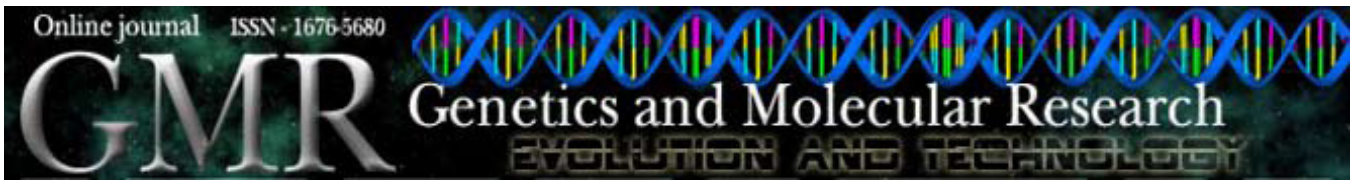

\title{
In vivo determination of genotoxicity induced by metals from orthodontic appliances using micronucleus and comet assays
}

\author{
G.H. Westphalen ${ }^{1}$, L.M. Menezes ${ }^{1}$, D. Prá ${ }^{2}$, G.G. Garcia ${ }^{1}$, \\ V.M. Schmitt ${ }^{1}$, J.A.P. Henriques ${ }^{2}$ and R. Medina-Silva ${ }^{1}$ \\ ${ }^{1}$ Departamento de Odontologia Preventiva, Pontifícia Universidade Católica \\ do Rio Grande do Sul, Porto Alegre, RS, Brasil \\ ${ }^{2}$ Departamento de Biofísica, Universidade Federal do Rio Grande do Sul, Porto \\ Alegre, RS, Brasil \\ Corresponding author: G.H. Westphalen \\ E-mail: grazihw@yahoo.com.br
}

Genet. Mol. Res. 7 (4): 1259-1266 (2008)

Received August 7, 2008

Accepted October 7, 2008

Published November 11, 2008

\begin{abstract}
Orthodontic appliances are usually made of stainless steel, which contains metals such as nickel, chromium and iron that have been associated with DNA damage. The aim of the present study was to determine the genetic toxicity associated with orthodontic fixed appliances in twenty healthy patients ( $16 \pm 2.5$ years $)$ undergoing orthodontic treatment (fixed appliances - basic composition: stainless steel alloy), using the micronucleus (MN) and comet (CA) assays in buccal cells. Primary DNA damage level, as assessed by the CA, was low either before the beginning ( $1.5 \pm 1.05$ damage index - DI) or 10 days after the placement of the orthodontic appliance $(2.5 \pm 3.08 \mathrm{DI})$ and did not change significantly between these time points $(\mathrm{P}=0.0913)$. Conversely, there was a significant increase in $\mathrm{MN}$ frequency 30 days after the beginning of the treatment $(\mathrm{P}=0.0236)$. In this study, the $\mathrm{MN}$ assay was shown to be more sensitive than the CA. Other investigations are necessary in order to assess the genotoxic potential of orthodontic fixed appliances associated with long-term studies concerning these effects in orthodontic patients.
\end{abstract}

Key words: Genotoxicity; Mutagenic tests; Metals;

Dental materials; Orthodontics 


\section{INTRODUCTION}

Orthodontic appliances are usually made of stainless steel alloy, which contains metals such as chromium, nickel and iron (Staerkjaer and Menné, 1990; Bass et al., 1993). The mouth properties (thermal, microbiological and enzymatic) offer an ideal environment for the biodegradation of orthodontic appliances (Faccioni et al., 2003; Thomas et al., 2007, 2008; Amini et al., 2008; Matos de Souza and Macedo de Menezes, 2008), consequently facilitating the release of metal ions that are related to adverse health effects, such as cellular and genetic toxicity (Munksgaard, 1992; Wataha, 2000; Dayan and Paine, 2001; Valko et al., 2005; Thomas et al., 2007, 2008).

Genotoxicity comprises either mutagenic or carcinogenic processes. Thus, the genotoxic properties of metals from orthodontic appliances are defined as an essential criterion to select these materials in a safe biological manner for patients (Montanaro et al., 2005).

The assessment of genotoxic agents can be performed through the application of some well-established endpoints such as the micronucleus (MN) frequency, as determined by the MN assay, or primary DNA damage, as accessed by the comet assay (CA). The combination of the two assays is considered to be very beneficial, because they show supplementary characteristics (Van Goethem et al., 1997). The MN assay is based on the frequency of $\mathrm{MN}$, structures that originate from chromosome fragments or whole chromosomes that are not included in the main daughter nuclei during nuclear division (Fenech et al., 1999). Thus, MN may arise from either DNA breakage leading to acentric chromosome fragments or from chromosome/chromatin lagging in anaphase. The formation of $\mathrm{MN}$ is considered to be an effective biomarker of diseases and processes associated with the induction of DNA damage. Another assay that has been indicated in order to complement the MN result is the alkaline single cell gel electrophoresis assay (Van Goethem et al., 1997), the CA, which measures single- and/or double-strand breaks in a cell by the cell approach. The CA is considered a quick, simple, sensitive, reliable, and fairly inexpensive way of measuring DNA damage (Collins et al., 1997).

The aim of the present research was to determine the genotoxicity induced by metals from orthodontic appliances, by employing both the MN and the CA in a group of healthy patients undergoing orthodontic treatment.

\section{MATERIAL AND METHODS}

\section{Patients and treatment}

Twenty healthy patients (14 females) with an average age of $16 \pm 2.5$ years, undergoing orthodontic treatment, were enrolled in this study. Orthodontic appliances were made of stainless steel $(0.07 \%$ carbon, $1.0 \%$ manganese, $1.0 \%$ silicon, $15.5-17.5 \%$ chromium, $3-5 \%$ nickel, $3-5 \%$ copper, $0.15-0.45 \%$ niobium + tantalum) in both arches, consisting basically of an average of 20 bonded brackets and four bands (3M Unitek ${ }^{\circledR}$, Monrovia, CA, USA). Smoking or drinking or illnesses related to any genetic damage increase were not reported by any patient. The patients' consent was obtained after a full explanation of the objective of the study. The research was approved by the University's Ethics Committee (Pontifícia Universidade do Rio Grande do Sul, Brazil). 


\section{Buccal cell sampling}

The samples were collected before (control) and after the placement of the orthodontic appliances. For the CA, the samples were obtained before and 10 days after the placement of the orthodontic appliances. For the MN assay, cells were sampled before and 30 days after the placement of the orthodontic appliances. Buccal cells were collected from each individual by gentle brushing of the inside part of the lower lip with a cytological brush, after washing out the mouth several times with tepid distilled water to remove exfoliated dead cells. The brushes were stirred in 50-mL plastic tubes containing $20 \mathrm{~mL}$ phosphate-buffered saline (PBS). Cells were washed twice, with centrifugation at $1500 \mathrm{rpm}$ for $10 \mathrm{~min}$ at room temperature, and resuspended in PBS, which was employed for the CA or MN assay.

\section{Comet assay}

The alkaline version of the CA was employed in this study (Speit and Hartmann, 1999; Faccioni et al., 2003). Briefly, $10 \mu \mathrm{L}$ cell suspension was mixed with $75 \mu \mathrm{L}$ low-melting-point agarose $(0.7 \%)$ and added to a slide precoated with $100 \mu \mathrm{L}$ agarose $(1 \%)$. Lysis was performed overnight at $\mathrm{pH} 10$. Cells were then placed in a electrophoresis chamber, exposed to alkali, $\mathrm{pH} \mathrm{13}$, for $25 \mathrm{~min}$, and electrophoresis was performed for $20 \mathrm{~min}$ at $25 \mathrm{~V}(0.86$ $\mathrm{V} / \mathrm{cm}$ ) and $300 \mathrm{~mA}$, at room temperature. The slides were neutralized, fixed, and stained with silver nitrate (Nadin et al., 2001). The slides were examined under a light microscope (Axiolab, Zeiss) at 1000X magnification. Fifty randomly selected cells of each subject (25 cells for each of two replicate slides) were visually scored according to five classes, based on tail size (from undamaged - 0, to maximally damaged - 4). Damage index (DI) was thus assigned to each individual, according to the sum of the classes attributed to each cell, ranging from 0 (completely undamaged: 50 cells $x$ ) to 200 (with maximum damage: 50 cells $x$ 4) (Hartmann et al., 2003). The DI is based on the length of migration and on the amount of DNA in the tail and is considered to be a sensitive measure of DNA. International guidelines and recommendations for the CA consider that visual scoring of comets is a well-validated evaluation method as it is highly correlated with computer-based image analysis (Burlinson et al., 2007).

\section{Micronucleus assay}

Buccal cells were collected and analyzed according to a standard protocol described elsewhere by Titenko-Holland et al. (1994). Slides of buccal cells were prepared by dropping the washed cell suspension onto pre-warmed slides $\left(37^{\circ} \mathrm{C}\right)$. After dropping, the cells were allowed to air-dry and fixed in methanol $(80 \%, \mathrm{v} / \mathrm{v})$ at $0^{\circ} \mathrm{C}$ for $20 \mathrm{~min}$. Staining was performed with May-GrunwaldGiemsa according to a standard protocol (Titenko-Holland et al., 1994). Only cells that were not smeared, clumped or overlapping and that contained intact nuclei were included in the analysis. MN were identified according to the following characteristics: i) less than $1 / 3$ diameter of the main nucleus; ii) the same plane of focus; iii) the same color, texture and refraction as the main nucleus; iv) smooth oval or round shape, and v) clearly separated from the main nucleus (Titenko-Holland et al., 1994). Cells were observed in oil immersion at 1000X magnification with a light microscope (Axiolab, Zeiss) to determine the presence of MN cells, as established by Sarto et al., 1987. 


\section{Statistical analysis}

The one-tailed $t$-test with Welch's correction was used to compare DI obtained by the $\mathrm{CA}$, and the one-tailed Fisher exact test was used to compare the number of patients with MN before and after the placement of orthodontic appliance.

\section{RESULTS}

Primary DNA damage level, as assessed by the CA, was low either before the beginning $(1.5 \pm 1.05)$ or 10 days after the placement of orthodontic appliance $(2.5 \pm 3.08)$ and did not change significantly between these time points $(\mathrm{P}=0.0913)$. Most cells were classified as class 0 regarding DNA damage extent, as depicted in Figure 1.
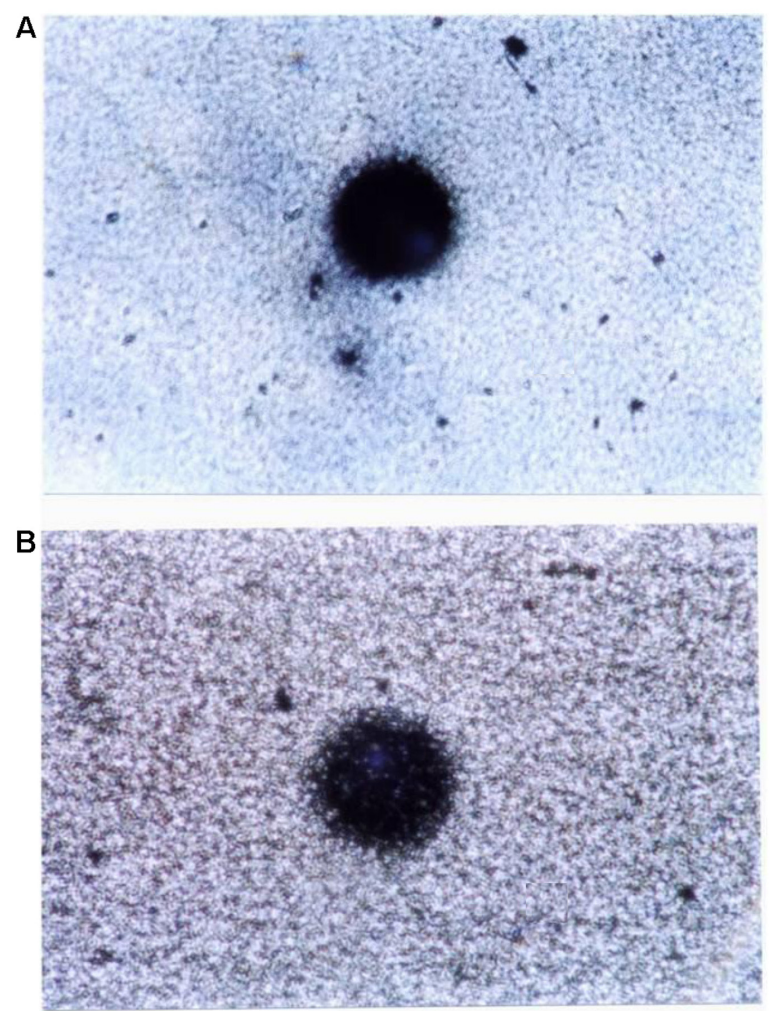

Figure 1. The comet assay. Nuclei of oral epithelium cells (1000X magnification) from a male patient, 11 years old, classified as zero class, before (A) and 10 days after (B) the placement of the orthodontic appliance.

Conversely, there was a significant increase in MN frequency $(\mathrm{P}=0.0213) 30$ days after the placement of orthodontic appliances (Table 1). Figure 2 illustrates an MN cell at 30 days after the placement of the orthodontic appliance. 
Table 1. Comparison of mononuclear (MN) cell frequency in the periods before and 30 days after the placement of orthodontic appliances.

\begin{tabular}{lcrrrr}
\hline MN cells/1000 cells & \multicolumn{2}{c}{ Before } & & \multicolumn{2}{c}{ After 30 dias } \\
\cline { 2 - 3 } \cline { 5 - 5 } & Number of cases & $\%$ & 100 & Number of cases & $\%$ \\
\hline 0 & 20 & 0 & 15 & 75 \\
1 & 0 & 0 & 2 & 5 \\
2 & 0 & 0 & 2 & 10 \\
3 & 0 & 100 & 20 & 100 \\
Total & 20 & &
\end{tabular}
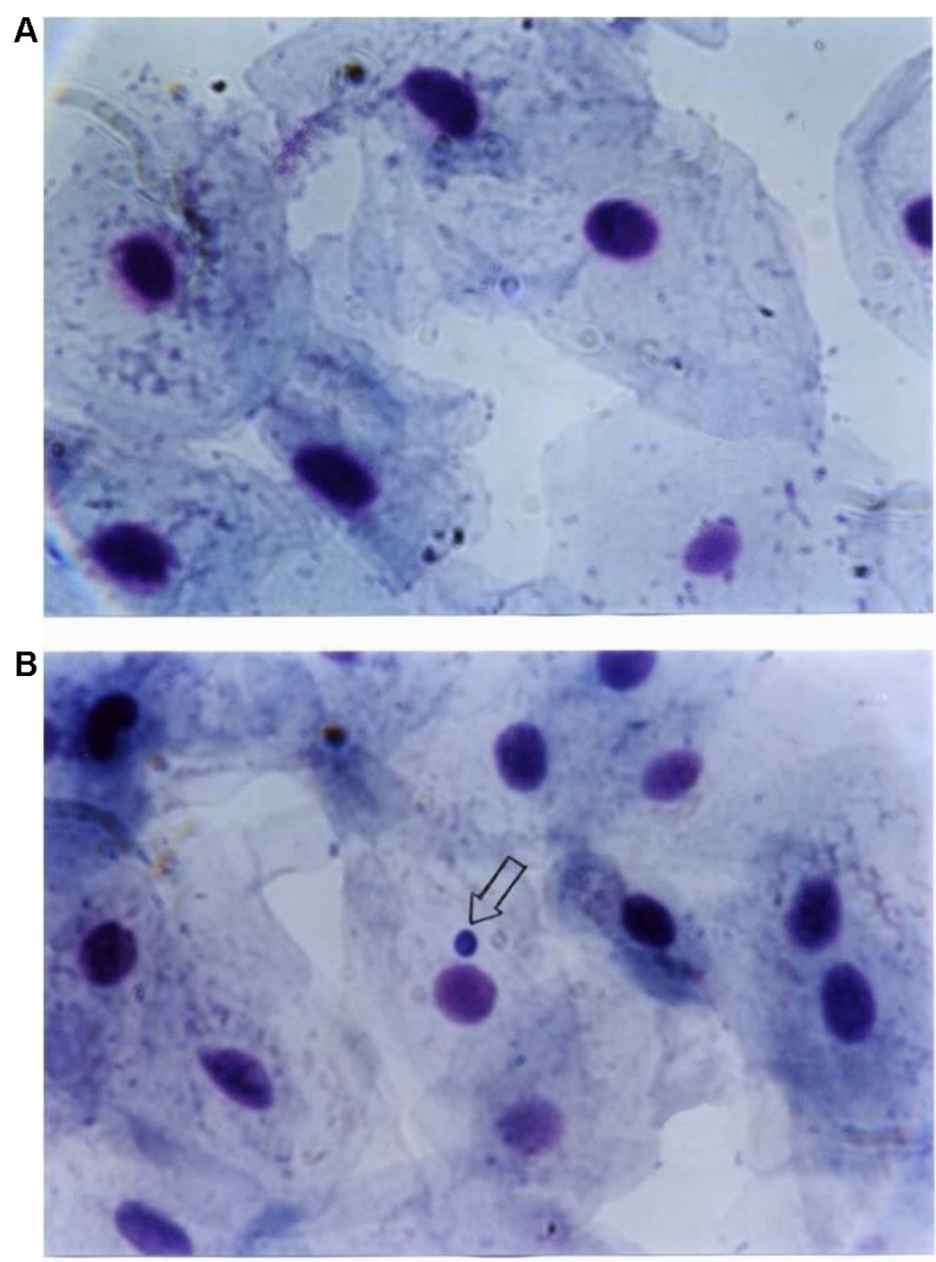

Figure 2. The micronucleus test. Cells of the oral epithelium (1000X magnification) from a female patient, 20 years old. A. Before and B. After 30 days of placement of orthodontic appliances. One micronucleus is indicated (arrow) in a binucleated cell in B. 


\section{DISCUSSION}

When orthodontic appliances are present in the oral cavity they are usually subject to corrosion processes, which lead to the release of metals (Ağaoğlu et al., 2001; Levrini et al., 2006; Matos de Souza and Macedo de Menezes, 2008). Some metallic elements present in orthodontic appliances, such as nickel and chromium, are known to be potential carcinogenic and mutagenic agents (Currents Conferences, 1984; Oller et al., 1997; Novelli et al., 1998; Wataha, 2000; Dayan and Paine, 2001; Burgaz et al., 2002; Costa, 2002; Zoroddu et al., 2002). The amount of metals released from orthodontic appliances in saliva or blood samples was significantly below the average dietary intake and did not reach toxic concentrations (Kocadereli et al., 2000; Ağaoğlu et al., 2001). However, it cannot be excluded that even nontoxic concentrations could be sufficient to induce biological effects in cells from the oral mucosa (Faccioni et al., 2003).

Current in vivo studies are aimed at representing the real condition of the oral cavity by sampling buccal cells, which are directly exposed to the appliances (Faccioni et al., 2003). Besides, there are some advantages of using this cell type: it is the least invasive method available for measuring DNA damage, and these cells could represent a preferred target site for early genotoxic events induced by carcinogenic agents entering the body via inhalation and ingestion (Jones et al., 1994; Holland et al., 2008). A cytobrush was used for sampling, which appears to be the most effective technique for collecting large numbers of oral mucosa cells (Holland et al., 2008).

Genotoxicity effects from orthodontic appliances were assessed by carrying out both MN and CA assays. This combination is recommended, since the CA could detect primary DNA damage (reparable) in a short period of time, while the MN assay detects chromosomal damage in a further stage (Van Goethem et al., 1997; Vrzoc and Petras, 1997). Therefore, the time of sampling was 10 days after the placement of the orthodontic appliance for the CA and 20 days later ( 30 days from the beginning of the exposure) for MN assay. The sampling time was suitable for a trial involving volunteers, and standard protocols were applied for both assays (Titenko-Holland et al., 1994; Speit and Hartmann, 1999). Nonetheless, since the viability of the buccal cells was not accessed in the present study, the results of the CA should be interpreted with caution.

CA has been used successfully to monitor DNA damage in human populations (Collins et al., 1997; Speit and Hartmann, 1999), and thus, it had a relevant application in this research. Moreover, it is a quick, simple, sensitive, reliable, and fairly inexpensive way of measuring DNA damage (Collins et al., 1997). In this research, the CA results reveal that orthodontic appliances did not induce any genetic damage. Similar findings were observed when CA was carried out in cultured human gingival keratinocytes exposed for up to 14 days to orthodontic brackets (Tomakidi et al., 2000). On the other hand, when the CA was applied in an in vivo study (55 orthodontic patients and 30 control subjects), it was demonstrated that metallic ions such as nickel and cobalt released from orthodontic appliances could induce DNA damage in oral mucosa cells (Faccioni et al., 2003). This difference may be explained by the fact that this previous study was a cross-sectional study associated with a larger number of patients analyzed using the appliances for a much longer period (2-3 years).

The MN assay has been applied in biological monitoring of human populations exposed to a variety of mutagenic and carcinogenic chemical or physical agents (Holland et al., 2008). The MN assay showed an increase in MN cells 30 days after the placement of the orthodontic appliances. A similar increase has been observed in epithelial cells exposed to some metals (Benova et 
al., 2002; Burgaz et al., 2002; Danadevi et al., 2004; Lewiska, 2007). However, no trials have been reported verifying genotoxicity induced by metals from orthodontic appliances.

Despite the MN increase observed, orthodontic materials have not exhibited cytotoxicity or genotoxicity in several trials (Wever et al., 1997; Assad et al., 2002a,b; Montanaro et al., 2005).

The difference in results between the two assays usually occurs due to specific genetic endpoints that each of them is able to elicit. Generally, the CA detects more DNA damage than the MN assay. Positive results in the CA do not always correspond to positive results in the MN assay, especially when the exposure to genotoxic agents is small (Van Goethem et al., 1997; Martino-Roth et al., 2003; Silva et al., 2003; Ribeiro et al., 2003). Nevertheless, in this study the MN assay was shown to be more sensitive than the CA. Furthermore, the assays were conducted at different times and a smaller number of cell samples were analyzed in the CA.

The divergence of results found in this study, the little research in this field and the importance of this subject for the health status of orthodontic patients are reasons for further studies with larger samples and long-term follow-up analysis. These strategies will yield valuable data in order to better understand the genotoxic potential of metals from orthodontic devices, as well as to access the biological risk to which orthodontic patients may be submitted.

\section{REFERENCES}

Ağaoğlu G, Arun T, Izgi B and Yarat A (2001). Nickel and chromium levels in the saliva and serum of patients with fixed orthodontic appliances. Angle Orthod. 71:375-379.

Amini F, Borzabadi FA, Jafari A and Rabbani M (2008). In vivo study of metal content of oral mucosa cells in patients with and without fixed orthodontic appliances. Orthod. Craniofac. Res. 11: 51-56.

Assad M, Chernyshov A, Leroux MA and Rivard CH (2002a). A new porous titanium-nickel alloy: part 1. Cytotoxicity and genotoxicity evaluation. Biomed. Mater. Eng. 12: 225-237.

Assad M, Chernyshov A, Leroux MA and Rivard CH (2002b). A new porous titanium-nickel alloy: part 2. Sensitization, irritation and acute systemic toxicity evaluation. Biomed. Mater. Eng. 12: 339-346.

Bass JK, Fine H and Cisneros GJ (1993). Nickel hypersensitivity in the orthodontic patient. Am. J. Orthod. Dentofacial Orthop. 103: 280-285.

Benova D, Hadjidekova V, Hristova R, Nikolova T, et al. (2002). Cytogenetic effects of hexavalent chromium in Bulgarian chromium platers. Mutat. Res. 514: 29-38.

Burgaz S, Demircigil GC, Yilmazer M, Ertas N, et al. (2002). Assessment of cytogenetic damage in lymphocytes and in exfoliated nasal cells of dental laboratory technicians exposed to chromium, cobalt, and nickel. Mutat. Res. 521: 47-56.

Burlinson B, Tice RR, Speit G, Agurell E, et al. (2007). Fourth international workgroup on genotoxicity testing: results of the in vivo comet assay workgroup. Mutat. Res. 627: 31-35.

Collins AR, Dobson VL, Dusinská M, Kennedy G, et al. (1997). The comet assay: what can it really tell us? Mutat. Res. 375: 183-193.

Costa M (2002). Molecular mechanisms of nickel carcinogenesis. Biol. Chem. 383: 961-967.

Currents Conferences (1984). Workshop: biocompatibility of metals in dentistry. J. Am. Dent. Assoc. 109: 469-471.

Danadevi K, Rozati R, Banu BS and Grover P (2004). Genotoxic evaluation of welders occupationally exposed to chromium and nickel using the Comet and micronucleus assays. Mutagenesis 19: 35-41.

Dayan AD and Paine AJ (2001). Mechanisms of chromium toxicity, carcinogenicity and allergenicity: review of the literature from 1985 to 2000. Hum. Exp. Toxicol. 20: 439-451.

Faccioni F, Franceschetti P, Cerpelloni M and Fracasso ME (2003). In vivo study on metal release from fixed orthodontic appliances and DNA damage in oral mucosa cells. Am. J. Orthod. Dentofacial Orthop. 124: 687-693.

Fenech M, Holland N, Chang WP, Zeiger E, et al. (1999). The human microNucleus project - An international collaborative study on the use of the micronucleus technique for measuring DNA damage in humans. Mutat. Res. 428: 271-283.

Hartmann A, Agurell E, Beevers C, Brendler-Schwaab S, et al. (2003). Recommendations for conducting the in vivo alkaline Comet assay. 4th International Comet Assay Workshop. Mutagenesis 18: 45-51.

Holland N, Bolognesi C, Kirsch-Volders M, Bonassi S, et al. (2008). The micronucleus assay in human buccal cells as a tool for biomonitoring DNA damage: the HUMN project perspective on current status and knowledge gaps. Mutat. 
Res. 659: 93-108.

Jones AC, Pink FE, Sandow OL, Stewart CM, et al. (1994). The cytobrush plus cell collector in oral cytology. Oral Surg. Oral Med. Oral Pathol. 77: 101-104.

Kocadereli L, Atac PA, Kale PS and Ozer D (2000). Salivary nickel and chromium in patients with fixed orthodontic appliances. Angle Orthod. 70: 431-434.

Levrini L, Lusvardi G and Gentile D (2006). Nickel ions release in patients with fixed orthodontic appliances. Minerva Stomatol. 55: 115-121.

Lewiska D, Palus J, Stepnik M, Dziubaltowska E, et al. (2007). Micronucleus frequency in peripheral blood lymphocytes and buccal mucosa cells of copper smelter workers, with special regard to arsenic exposure. Int. Arch. Occup. Environ. Health 80: 371-380.

Martino-Roth MG, Viégas J and Roth DM (2003). Occupational genotoxicity risk evaluation through the comet assay and the micronucleus test. Genet. Mol. Res. 2: 410-417.

Matos de Souza R and Macedo de Menezes L (2008). Nickel, chromium and iron levels in the saliva of patients with simulated fixed orthodontic appliances. Angle Orthod. 78: 345-350.

Montanaro L, Cervellati M, Campoccia D, Prati C, et al. (2005). No genotoxicity of a new nickel-free stainless steel. Int. J. Artif. Organs 28: 58-65.

Munksgaard EC (1992). Toxicology versus allergy in restorative dentistry. Adv. Dent. Res. 6: 17-21.

Nadin SB, Vargas-Roig LM and Ciocca DR (2001). A silver staining method for single-cell gel assay. J. Histochem. Cytochem. 49: 1183-1186.

Novelli ELB, Hernandes RT, Novelli Filho JLVB and Barbosa LL (1998). Differential/combined effect of water contamination with cadmium and nickel on tissues of rats. Environ. Pollution 103: 295-300.

Oller AR, Costa M and Oberdörster G (1997). Carcinogenicity assessment of selected nickel compounds. Toxicol. Appl. Pharmacol. 143: 152-166.

Ribeiro LR, Salvadori DMF and Marques EK (2003). Mutagênese Ambiental. 1st edn. Ulbra, Canoas.

Sarto F, Finotto S, Giacomelli L, Mazzotti D, et al. (1987). The micronucleus assay in exfoliated cells of the human buccal mucosa. Mutagenesis 2: 11-17.

Silva J, Erdtmann B and Henriques JAP (2003). Genética Toxicológica. 1st edn. Alcance, Porto Alegre.

Speit G and Hartmann A (1999). The comet assay (single-cell gel test). A sensitive genotoxicity test for the detection of DNA damage and repair. Methods Mol. Biol. 113: 203-212.

Staerkjaer L and Menné T (1990). Nickel allergy and orthodontic treatment. Eur. J. Orthod. 12: 284-289.

Thomas P, Hecker J, Faunt J and Fenech M (2007). Buccal micronucleus cytome biomarkers may be associated with Alzheimer's disease. Mutagenesis 22: 371-379.

Thomas P, Harvey S, Gruner T and Fenech M (2008). The buccal cytome and micronucleus frequency is substantially altered in Down's syndrome and normal ageing compared to young healthy controls. Mutat. Res. 638: 37-47.

Titenko-Holland N, Moore LE and Smith MT (1994). Measurement and characterization of micronuclei in exfoliated human cells by fluorescence in situ hybridization with a centromeric probe. Mutat. Res. 312: 39-50.

Tomakidi P, Koke U, Kern R, Erdinger L, et al. (2000). Assessment of acute cyto- and genotoxicity of corrosion eluates obtained from orthodontic materials using monolayer cultures of immortalized human gingival keratinocytes. $J$. Orofac. Orthop. 61: 2-19.

Valko M, Morris H and Cronin MT (2005). Metals, toxicity and oxidative stress. Curr. Med. Chem. 12: 1161-1208.

Van Goethem F, Lison D and Kirsch-Volders M (1997). Comparative evaluation of the in vitro micronucleus test and the alkaline single cell gel electrophoresis assay for the detection of DNA damaging agents: genotoxic effects of cobalt powder, tungsten carbide and cobalt-tungsten carbide. Mutat. Res. 392: 31-43.

Vrzoc M and Petras ML (1997). Comparison of alkaline single cell gel (Comet) and peripheral blood micronucleus assays in detecting DNA damage caused by direct and indirect acting mutagens. Mutat. Res. 381: 31-40.

Wataha JC (2000). Biocompatibility of dental casting alloys: a review. J. Prosthet. Dent. 83: 223-234.

Wever DJ, Veldhuizen AG, Sanders MM, Schakenraad JM, et al. (1997). Cytotoxic, allergic and genotoxic activity of a nickel-titanium alloy. Biomaterials 18: 1115-1120.

Zoroddu MA, Schinocca L, Kowalik-Jankowska T, Kozlowski H, et al. (2002). Molecular mechanisms in nickel carcinogenesis: modeling Ni(II) binding site in histone H4. Environ Health Perspect. 110 (Suppl 5): 719-723. 